\title{
Integration of Music Teaching and Native Ethnic Music in Yunnan's Institutions of Higher Learning
}

\author{
Xiulei Ren \\ Scholl of Music and Dance \\ Qujing Normal University \\ Qujing, Yunnan, China 655011
}

\begin{abstract}
Ethnic music is an important part of Chinese music treasure. It reflects minority's love and passion for life, expectation for happy life and positive spirituality during their laboring. Yunnan is a province that is inhabited by the most minorities and different minorities have diversified musical culture characteristics. The ethnic music of Yunnan Province has its unique natural and ecological environment, humanistic affection carrier and musical features. Therefore, in their teaching activities, the colleges and universities of Yunnan Province should pay much more attention on introducing local music into class. The spreading of original ethnic music in colleges and universities is helpful for protecting, inheriting, promoting our traditional Chinese culture, and a response to a national call that is protecting our nonmaterial culture as well.
\end{abstract}

Keywords-colleges and universities of Yunnan province; music teaching; local music; ethnic music culture; integration

\section{INTRODUCTION}

Ethnic music "South of the Clouds" and "Guests from afar, Please Stay" are echoing, "Beside Butterfly Spring" resounds. It is well-known that Yunnan Province is the paradise of folk music and customs. Diligent minority compatriots created numerous brilliant custom culture and musical culture during their thousands of years of laboring. Melodious Tibetan music is echoing on Diqing Plateau; music of Ailao Mountains reverberates through Yunnan; sounds of nature resound from Three Parallel Rivers to the source of Zhujiang River, from Jinsha River bank to Honghe River. Its profound historical deposits, tremendous inclusiveness and unique ethnic features are praised and yearned for by all human beings.

Local music stems from the music root of inner heart, including mother tongue and folk customs; style, color, mode, tonality and theory of tone. The forms of Yunnan ethnic music are various and most of the music reflecting working people's life and eulogizing happy life are original. The musical history of $\mathrm{Yi}$ nationality inhabiting beside Honghe River is intricate, having many branches; such as "eating Huocaoyan" and "Four tones" full of life fun, "Tiaoxian" with fixed talking and singing melody and group singing and dancing; "Dagediao" "Datiao" and "Left foot dance" of Yi nationality in Chuxiong; "Sani Venus" of Lipo and Guoluo music branch, ancient "Ashima", the "Oriental carnival" Torch Festival. An instrument, Paimang for festival celebration and Peacock Dance and Horse Deer Dance, world- famous instrument Xun (a holed wind instrument), distinctive "Small Stuffy Flute", elaborate "Tuliang" "Chiba" and "morin khuur" "Hulusi (cucurbit flute)". Stereoscopic constructing the talking and singing, opera, music and dance, integrating and researching folk music, instruments and religious music can not only contribute to the researches of ethnic music history, but also influence ethnic music development history, way of living and thinking, forms of artistic creation and moral values.

However, everything has its pros and cons. Now that it has its advantages to be praised, it also has disadvantages that will hinder its development in the future. As for ethnic musical culture, it is faced with severe challenges. First, a lot of precious written original records disappeared since they were not systematically taken good care of. Second, ethnic music are not recorded in words, so it is very difficult to be inherited and encounters with extinction. Since it is not paid much attention, with the passage of time, it has lost a lot of public praise. Third, with the passage of generations, those ethnic priests, folk artists and custom lovers who are familiar with and can master and skillfully use ethnic music withdraw from the historical stage. Ethnic musical culture is difficult to inherit; ancient classics and brilliant epics are rarely known by public and ethnic music lacks inheritor talents. Forth, with the development of economy, especially tourism-driven economy, ethnic music easily loses its pureness. In order to cater to some tourists' curiosity, some places and organizations purposely misinterpret even counterfeit ethnic music and culture; or they arbitrarily reveal traditional taboos, which violates the original intention of ethnic music and hurts older generation's hearts.

The root of minorities' ethnic music is not only the fertile field that raises ethnic music, but also spot systematical teaching. With the conversion of original musical culture, increasing competition of world's music and oppression of pop music, the keynote, pattern and approach of ethnic music development cannot be the traditional single form and they should be diversified. In such a circumstance, local music colleges should stand out as important music platforms; however, some problems in college music education are worth serious consideration. First, the development of music education system of China is based on Western professional music education, and it is deeply influenced by Western culture; therefore there are obvious traces of plagiarism and 
imitation. The so-called Western pop, rap, jazz and rock music are enthusiastically chased after; the younger generation students even music teachers are not keen on Chinese music, especially opera music and religious music. They are unfamiliar with Chinese ethnic culture and artistic traditions and rusty on idea realization, value delivery and culture and art of ethnic original works. Traditional music education pattern is that teachers interpret musical theories on the class and students repeatedly sing the song. The artistic connotation, style and rhyme and cultural background are superficially understood; the real interior mining is rare; and even if there are, most of them are professors' or Doctor's degree dissertation research for conferring of academic titles, but the original appearance, ethnic historical background and the core of spirituality reflected by the dense written words are dry and boring; they are difficult to be accepted, learnt and adopted by students. Second, Chinese music colleges students lack the sense of inheriting, of independent creation, subjective initiative and creativity; they can perform Western classics and clearly tell foreign musical culture in the pursuit of Western music, but they think Chinese ethnic music is primitive and out of date. Ethnic music is the source and indigenous culture is the spirit. Without source and sprit, the music education of colleges will be in danger. Facing unique music forms, cultural carriers and sign patterns of minorities, young students' value deviation is of concern. Especially on the impact of foreign pop culture and urban music, it is very hard for young students to appreciate the subtlety of traditional Chinese culture, aesthetics, sentiment and belief of minorities and the unique charm of pure indigenous operas and songs. It is because of such worrisome problems, college music education should take responsibility to development ethnic music.

\section{COLLECTING AND INTEGRATING OF MinORITIES' ETHNIC MUSIC OF YUNNAN PROVINCE}

Integrating means to tidy, link up, regroup and unite those scattered, dispersive, partial and fragmentary units in a certain scientific or effective way for the purpose of information sharing, resource sharing and collaborative management; eventually generate group effect that has eternal value and super-high efficiency.

In March 2005, General Office of the State Council issued Interim Measures for the Declaration and Evaluation of the National Intangible Cultural Heritage Representative, authoritatively defining non-material cultural heritage. As the traditional performance art of minorities, ethnic music was included in the scope. National policies and regulations protect the ethnic music and indigenous culture in a macro way; from the micro perspective, local governments, folk artists and related educators collect, conclude and integrate specific and detailed information of ethnic music. Owing to historical change, transition of ideas, despising and arbitrary abandonment of minorities' indigenous music, the music forms and instruments of minorities are incomplete. Music of Yi nationality of Dieshi Village now is fragmentary and few music forms such as Luomeng exist. Ballad epics of $\mathrm{Nu}$ nationality nowadays are also extremely rare. In addition, most minorities do not have written languages as recording medium, so they disappear year by year. Thus, our art works especially educators in colleges should collect, conclude, tidy and file minorities' fragmentary and partial music forms and genres in a way "Sanxiaxiang"1 to enter ethnic tribes. As for those minorities having written languages, we should collect and accumulate as much as possible ethnic music, abstract and generalize those music; as for those non-written-language minorities, their spoken language and contents should be put into words, and a set of simple, routinized literal code, numeric character and gesture language should be established for recording.

\section{CONSTRUCting A NeW Music Teaching AND EDUCATION SYSTEM IN COLLEGES}

The dimensional new teaching system focuses on "learning-guiding" pattern. Update teaching concept, get familiar with local teaching materials and have a full understanding of students' characters; combine these three approaches to design heuristic courses that not only meet with the era but also link up with indigenous ethnic resource. Construct a new system combining basic theoretical course and practice teaching course, which aims to promote college students' indigenous music quality, sense of resource fusion and ethnic humanistic feelings.

\section{A. Three-dimensional Indigenous Teaching Theory}

Learning ethnic music of Yunnan is neither indiscriminately copying of meanings and forms in Darwin's sense, nor wearing minorities' costumes. Students cannot just express its superficial meaning from perceptual level; they should also dig into its primitive background, humanistic feelings and value pursuit from a deeper sense. First, we should have the awareness that minorities are beautiful; minority people are beautiful; the young lady singing folk music is beautiful; the untie singing and washing beside the river is beautiful and the young man carrying a hoe singing to his beloved is beautiful. Therefore, students in class should always be indoctrinated that indigenous music is not rustic but elegant to make students love ethnic music, hope to get in touch with ethnic objects and have a strong desire to make contribution to ethnic music. Second, ethnic music of Yunnan should be put into the level of cultural core structure such as theory understanding, spirit understanding and practice discussing。 Guide students and interpret ethnic music from the perspective of its style and features, connotations, tint and elegance. Help students analyze, understand and grasp custom cultures from minorities' different features, functions and abundant forms.

Therefore, to guide students to attach importance to the aesthetic value of ethnic music from the perspective of culture accessing music is somehow difficult, which requires music colleges update their teaching theory, strengthen indigenous features and dig into its inner growing power.

\footnotetext{
${ }^{1}$ A program under which officials, doctors, scientist and college students go to the countryside to spread scientific and literacy knowledge and offer medical service to farmers
} 


\section{B. Three-dimensional Indigenous Teaching Model}

To guide college students to form scientific and ethnic view on world, life and value is the focus of Yunnan colleges' educative reform; the traditional music teaching model is usually cramming system "textbook - theory-examplesdemonstration - work handing over-comment on class", boring and stereotyped. Three-dimensional indigenous teaching method requires teacher to figure out the roles of themselves and their students in teaching practice. The new model emphasizes on the development of students' characters under the supervision of teachers and ability construction of self-directed learning. Stimulate their independence, imagination and creativity; encourage students to instruction teachers and learning from each other.

Three-dimensional indigenous teaching requires teachers to work out a flexible teaching method according to the features and laws of indigenous ethnic music, edit textbooks possessing ethnic features in line with theoretical knowledge of minorities. Educate students on the basis of indigenous musical structure; adopt the teaching model of "students preparing lessons, students giving lectures, teachers attending lectures, examining teachers and students summarizing". Students actively participate in the activities of teaching and learning. Teachers and students can promote their relationship through interaction; meanwhile, a high-quality first-class teachers' team based on the core students will be constructed.

\section{Three-dimensional Teaching Practice System}

Three-dimensional teaching practice can be conducted by the way of "summer vacation to countryside, winter vacation to villages"; lead students to live and work with minorities for a certain period of time; through their intimate contact, interaction, and emotion expressing to influence students mildly and make them self-conjecture, know different articulatory attributes, singing techniques and music structure. They can teach with interest, experience life and apply their knowledge to practice, which makes students' music creation full of national affection, orientation and effectiveness.

\section{CONSTRuCting A NeW Indigenous Ethnic Music TEACHING MODEL, "INTERNET +"}

Indigenous music teaching cannot just be writing on blackboards and giving lecture on class; it should be a new ethnic music teaching model which is "Internet +" to enforce traditional education to become innovative education. In the background of Opening-up, indigenous elements should be introduced to Chinese music repository to enrich high-quality education resource. After indigenous music is connected with the Internet and faculties are integrated, students can have access to the materials that they need at home or outside, which increases their learning efficiency, vivifies education institutes, strengthens teaching staff, re-assorts indigenous resources and reconstructs the indigenous "transgenic engineering".

\section{CONCLUSION}

College music teaching executors cannot just say words to inherit indigenous music of minorities, and they must put forward corresponding solutions. They should focus on integrating indigenous music of minorities, construct threedimensional music course system with national features, strengthen the construction of indigenous music teaching staff and establish a new indigenous music teaching model which is "Internet + ".

\section{References}

[1] Liu Ke \& Sun Jingmei, An Exploration and Analysis of College Piano Ethnic Music Teaching from the Perspective of Indigenous Musical Culture [J]. Ethnic Art Studies. 2014, 27 (5).

[2] Chu Chu, Inheritance of Yunnan Ethnic Music in Higher Art Education [J]. National Music. 2010, 01.

[3] Liu Kuili, Integration Principle of Non-material Cultural Heritage and Its Protection [J]. Journal of Guangxi Teachers Education University. 2004 (4)

[4] Zhang Xiaoman \& Ma Qiaomei, Inheritance of Indigenous Music in Local Colleges Music Education [J]. Big Stage, 2012 (8).

[5] Xia Yihe, Integration of Indigenous Musical Cultural Resources and Yunnan Colleges Music Education. Studies in National Art. 2011, 24 (4). 